Portland State University

PDXScholar

\title{
Identification of entry-level clerical/secretarial skills and competencies and utilization of hardware and software applications in Clark County businesses
}

Phyllis A. Maki

Portland State University

Follow this and additional works at: https://pdxscholar.library.pdx.edu/open_access_etds

Part of the Business Commons, and the Education Commons Let us know how access to this document benefits you.

\section{Recommended Citation}

Maki, Phyllis A., "Identification of entry-level clerical/secretarial skills and competencies and utilization of hardware and software applications in Clark County businesses" (1990). Dissertations and Theses. Paper 3496.

https://doi.org/10.15760/etd.5379

This Thesis is brought to you for free and open access. It has been accepted for inclusion in Dissertations and Theses by an authorized administrator of PDXScholar. Please contact us if we can make this document more accessible: pdxscholar@pdx.edu. 
IDENTIFICATION OF ENTRY-LEVEL CLERICAL/ SECRETARIAL SKILLS AND COMPETENCIES AND

UTILIZATION OF HARDWARE AND SOFTWARE

APPLICATIONS IN CLARK COUNTY BUSINESSES

by

PHYLLIS A. MAKI

A paper submitted in partial fullfillment of the requirements for the degree of

MASTER OF SCIENCE IN TEACHING

BUSINESS EDUCATION

and

BED 501

BUSINESS SURVEY

Portland State University

1990 
TABLE OF CONTENTS

PAGE

LIST OF TABLES . . . . . . . . . . . . . . . . . . . . iv CHAPTER

I DEVELOPMENT OF THE PROBLEM . . . . . . . . . . . . . . 1 Introduction . . . . . . . . . . . . . . . . . . 1 Need for Study . . . . . . . . . . . . . . . 2 Statement of Problem . . . . . . . . . . . 3 Purpose . . . . . . . . . . . . . . . . . 3 Delimitations . . . . . . . . . . . . . . 3 Summary . . . . . . . . . . . . . . . . 4

II REVIEW OF RELATED LITERATURE . . . . . . . . . . 5 The Changing Workforce . . . . . . . . . . 5 The Job Demand and Worker Skills Gap . . . . . . . . 9 General Competencies and Skills Desired by Employers 12 Secretarial Skills Desired . . . . . . . . . . . 14 Summary . . . . . . . . . . . . . . . . 19

II PROCEDURES AND METHODS . . . . . . . . . . . . 21 Methodology . . . . . . . . . . . . . 21 Subject Selection . . . . . . . . . . . . . 21 Questionnaire Design . . . . . . . . . . 22 Treatment of Data. . . . . . . . . . . . 24 
FINDINGS . . . . . . . . . . . . . . . . . 25

Analysis of Non-Response . . . . . . . . . . 25

Questionnaire Items and Findings . . . . . . . . 26

Summary . . . . . . . . . . . . . . . . 48

V CONCLUSIONS AND RECOMMENDATIONS . . . . . . . . . . 49

General Information . . . . . . . . . . . . . 49

Hardware and Software Usage . . . . . . . . . . 49

Competencies . . . . . . . . . . . . . . 50

Specific Technical and Vocational Skills . . . . . 51

Deficiencies of Entry-Level Employees . . . . . . . 52

Recommendations . . . . . . . . . . . . . 53

Summary . . . . . . . . . . . . . . 54

REFERENCES CITED . . . . . . . . . . . . . . 55

REFERENCES NOT CITED . . . . . . . . . . . . . . 59

APPENDIX A Cover Letter . . . . . . . . . . . . . 62

APPENDIX B Questionnaire . . . . . . . . . . . . . 63

APPENDIX C Brands/Models of Computers Businesses Now Own • 65

APPENDIX D Other Software Programs Companies Use . . . . . 66

APPENDIX E Software Used in Specific Program Areas . . . . 67

APPENDIX F Software Companies Plan to Purchase . . . . . . 69 


\section{LIST OF TABLES}

TABLE

PAGE

1. SAMPLE SELECTION OF FIRMS . . . . . . . . . . . 22

2. QUESTIONNAIRE RETURNS BY INDUSTRY . . . . . . . 25

3. RESPONSES BY INDUSTRY . . . . . . . . . . . . . . 26

4. CLERICAL/SECRETARIAL EMPLOYEES IN FIRMS . . . . . . 27

5. COMPUTERS BUSINESSES NOW OWN . . . . . . . . . . 28

6. COMPUTERS BUSINESS PLAN TO PURCHASE . . . . . . . 29

7. SOFTWARE BUSINESSES PRESENTLY USE . . . . . . . . . 30

8. SOFTWARE BUSINESSES PLAN TO PURCHASE . . . . . . . 31

9. COMPANIES USING A NETWORKED SYSTEM . . . . . . . . . 32

10. IMPORTANCE OF BASIC MATH AND SCIENCE SKILLS . . . . 33

11. IMPORTANCE OF INTERPERSONAL/HUMAN RELATIONS SKILLS - 33

12. IMPORTANCE OF WRITTEN/ORAL COMMUNICATION SKILLS . . 34

13. IMPORTANCE OF POSITIVE WORK HABITS AND ATTITUDES • • 35

14. IMPORTANCE OF REASONING AND PROBLEM-SOLVING SKILLS . 35

15. IMPORTANCE OF SPECIFIC TECHNICAL/VOCATIONAL SKILLS - 36

16. IMPORTANT COMPETENCIES OF HIGH SCHOOL GRADUATES • • 36

17. IMPORTANCE OF ACCOUNTING/BOOKKEEPING SKILLS . . . 37

18. IMPORTANCE OF DESKTOP PUBLISHING . . . . . . . . . . 38

19. IMPORTANCE OF DICTATION/TRANSCRIPTION SKILLS . . . . 39

20. IMPORTANCE OF ELECTRONIC CALCULATOR SKILLS . . . . 39

21. IMPORTANCE OF GENERAL OFFICE MACHINE SKILLS . . . 40 
22. IMPORTANCE OF KEYBOARDING/TYPING ACCURACY . . . . . 41

23. IMPORTANCE OF KEYBOARDING/TYPING SPEEDS OF 25-50 WPM 41

24. IMPORTANCE OF KEYBOARDING/TYPING SPEED OF 50+ WPM - 42

25. IMPORTANCE OF COMPUTER OPERATING SYSTEM, SPREADSHEET, AND DATA BASE SKILLS . . . . . . 43

26. IMPORTANCE OF PROOFREADING SKILLS . . . . . . . . 43

27. IMPORTANCE OF SHORTHAND SKILLS . . . . . . . . . . . 44

28. IMPORTANCE OF SPELLING/GRAMMAR/PUNCTUATION SKILLS • 45

29. IMPORTANCE OF TELEPHONE TECHNIQUE SKILLS . . . . . . 45

30. IMPORTANT TECHNICAL/VOCATIONAL SKILLS . . . . . . . 46

31. DEFICIENCIES PERCEIVED IN ENTRY-LEVEL EMPLOYEES • . 47 
CHAPTER 1

DEVELOPMENT OF THE PROBLEM

\section{Introduction}

One objective of business education in the high school is to prepare young people for successful employment in today's job market. Training focuses on specific skills and knowledge as well as the development of good attitudes, management skills, leadership, dependability, and positive work habits required to meet the employer's needs.

Business educators achieve realism in the classroom by creating an atmosphere where the student can "live" the role of the job using the equipment and performing the tasks encountered on the job. Programs are designed to place people in office jobs. They include the improvement and practical application of basic skills in math, English, and communication as an integral part of the program.

The business office of today differs greatly from the office of even five years ago. With the advent of computerization, new technologies, and changing office structures, the standards of performance, and the skills and competencies required in current business education curricula may not be applicable to the office of the future. Office automation functions by using electronic technology and streamlining office systems procedures. Its goal is to increase the speed, accuracy, and convenience of communication forms. 
Technologies and changing office structures are putting tremendous pressure on educators to train students to meet the entry-level requirements of the office of the future. Many educators believe that the future of business education will depend on the educators' abilities to integrate computer instruction into the curriculum. Some believe that basic skills in reading, writing, and math, which have been taken for granted, are deficient and should take priority over job-specific skills training. Others maintain that competencies, or nontechnical skills, such as the ability to work effectively with a wide range of individuals, attitudes, and communication skills should be stressed.

\section{Need for Study}

Business educators need to provide relevant career education and train students adequately for entry-level work and success in a dynamic and changing society. It is imperative, then, we identify those skills, knowledges, and attitudes necessary for success not only in today's office but also in the office of the future.

To determine the competencies and skills required, a survey of businesses in the clark county area was completed. The questionnaire was designed to assess current computer usage and technical and nontechnical skill requirements. 
Responses to the questionnaire will guide planning and determine direction for future curriculum development in our district and should benefit business, students, and teachers.

Statement of Problem

The problem was to (1) identify the entry-level clerical/secretarial skills and competencies required in clark County businesses; and (2) determine utilization of microcomputer hardware and software applications.

\section{Purpose}

The purpose of this study was to gather data from businesses in order to evaluate equipment and review/update the curriculum in the business department at Prairie High School to better meet the needs of businesses hiring entry-level clerical/secretarial employees.

\section{Delimitations}

This study was limited to 160 businesses in Clark County, Washington as listed in the Greater Vancouver Chamber of Commerce Directory. All the businesses listed under the following categories were sent questionnaires:

(1) financial and investment

(2) government

(3) insurance 
(4) legal

(5) medical

(6) real estate.

\section{Summary}

Computerization and new technologies have changed the roles of workers in the business office today. Many educators believe that the future of business education will depend on their abilities to confront new challenges and train students to meet the entry-level requirements of the changing office.

A study was developed to gather information from clark County businesses to determine required entry-level clerical/secretarial skills and competencies and to ascertain the utilization of hardware and software applications.

Information gathered from this study will benefit business, educators, and students as curriculum is updated to better meet the needs of businesses hiring entry-level employees. 
CHAPTER I I

REVIEW OF RELATED LITERATURE

\section{The Changing Workforce}

Literature related to the office of the future deals with many topics, beginning with work-related trends and the exploration of the external environment and what that means for business growth and employment opportunities.

The economy is continuing its rush from a product or manufacturing economy to a service economy (45:29). In May of 1985 alone, 28,000 jobs were lost in manufacturing while 345,000 jobs were created in service industries. After 30 months of economic recovery, manufacturing had regained only about 60 percent of the jobs lost. Nine out of 10 new jobs created in 1985 were in the service sector. Service growth causes differentiation and specialization. One of the most notable demographic trends is the aging of the population which will provide employment opportunities and a creation of new products and services to this segment of the population. The shift to services also creates changes in location, hours, and structure of work as jobs tend to be located where and when the customer wants them instead of in a centralized location. As a result, a future workplace may have a shorter work week with fewer people employed full time or more people employed part-time (41:xvii). 
In Oregon, 178,000 new jobs will be created between 19862000. Almost $95 \%$ of these will be in nonmanufacturing, primarily in trade and service-oriented industries. Because annual pay for these jobs was approximately $73 \%$ of that in manufacturing in 1985, the trend indicates an increasing number of lower-paying and/or part-time jobs (2:8). Wages may also become less equally distributed, since service jobs tend to have more high and low wage earners with fewer in the middle (41:xvii). Skill levels in the service industries, however, are higher. While $80 \%$ of America's jobs do not require a college degree, they do require training $(6: 3)$. Perpetuating an educational system based on yesterday's industrial society will not meet the needs of today's technology-dependent world $(43: 3)$.

Work styles are changing partially because of the increase in technology. Automation, whether it is with telecommunication or computers, decentralizes work stations and requires a strong foundation of basic skills together with many additional skills. Increasingly, the roles of technician and problem solver are becoming inseparable and require workers to be adaptable and multi-skilled (1:1). The gradual collapse of the hierarchical structure is being replaced with team concepts such as quality circles and participatory management (45:30). This requires special communication abilities. Indeed, the secretary today is no longer one who answers the phone, types, and takes shorthand. Instead the secretary is one who is part of the management team. 
It will be possible by the late 1990's to dictate a memo into a machine that will electronically distribute it to offices around the world. Should a hard copy be needed, copiers linked to teleprinters will print, duplicate, and route the memo as well as file it in electronic memory banks (28:5).

The National Business Education Association (34:3) states that 95 percent of the businesses in this country have fewer than 50 employees. In comparison to larger firms, smaller companies tend to hire high school graduates with little or no work experience $(44: 22)$. The increase in smaller companies may mean increased job hopping, less job security, and fewer company-paid benefits. They may also contain more generalized job descriptions and flexible work rules that will increase the variety of job duties a worker will be expected to perform $(2: 10)$

Large companies, on the other hand, are placing high values on personnel development in order to be competitive. Many firms are creating incentive plans that pay for skills learned with bonuses to work teams that are high producers $(2: 11)$. More work group teams with fewer mid-level managers require workers to accept more responsibility.

Whether a worker is employed by a small or large company, adaptability to changes in employment is important because most of the jobs as we know them today will not exist in 2000 (16:2). It becomes essential that they be able to explore information, 
solve new problems, comprehend patterns, visualize relationships, and be able to work both individually and in work teams (16:2).

Jobs in the administrative support occupations are expected to grow rapidly due to the rapid growth of the service and finance sectors. While employment of computer and peripheral equipment operators is expected to rise rapidly through 1995 , employment of data-entry operators is expected to decline. Because of the steadily-growing need for information processors, opportunities for secretaries will show an average increase (5:97). Recent data indicates that by $1990,60 \%$ of the work force will be clerical and secretarial, and that by $2000,80 \%$ of the labor force will be be information workers (28:1). According to the Bureau of Labor Statistics, secretaries have the greatest potential in employment of all occupations (26:47). Stenographers, however, will decline due to the popularity of dictation machines. The "steno pool" is becoming a thing of the past $(5: 97)$.

The nation is facing a harsh demographic reality: the supply of new workers aged 16 to 24 is dwindling. The number of young workers in this age group will drop by 2 million, or eight percent $(41: x i x)$. There will be 20 percent fewer people, then, in the job-entry age group in this country $(7: 30)$ and an increase in middle-aged employees $(37: 262)$. The average age of the workforce will climb from 36 today to 39 by the year 2000 (41:xix). These facts have both positive and negative impacts. 
While the older workforce will be more experienced, stable, and reliable, they are also less adaptable $(2: 6)$. While they yield certain benefits such as higher productivity and an opportunity to maintain a low rate of inflation, they limit the upward mobility of many younger workers $(2: 6)$. Consequently, there will be a tighter labor market with more available entry-level positions $(39: 6)$.

Over the next 15 years, two thirds of all new workers will be women (31:11) and 61 percent of all women of working age are expected to have jobs $(41: 20)$. Although they may still be concentrated in jobs that pay less than men's jobs, they will be rapidly entering many higher-paying professional and technical fields.

The workplace will also become more multicultural. Nonwhites are projected to account for $29 \%$ of the net additions to the labor force by 2000. Many new entry-level workers will be recent immigrants, drawn largely from Asia and Latin America. By 2000 , then, $83 \%$ of the net additions to the workforce will be non-whites, women, and immigrants $(39: 6)$.

The Job Demand and Worker Skills Gap

While the workforce is becoming older and multicultural, industry is demanding much higher skill levels. Newly created jobs will increase in complexity and demand workers who have basic skills in language, mathematics, computer technology and critical thinking $(7: 30)$. Ironically, this will lead to both 
higher and lower unemployment: more joblessness among the leastskilled and less among the most educationally advantaged.

If current projections hold up, millions of young people will not have the training required to obtain and retain fulltime jobs. A special report written by Business Week states that while there is always a gap in a dynamic society between job demands and worker skills, the nation is now facing a "monumental mismatch between jobs and the ability of Americans to do them" (19:104). A joint initiative completed by the Departments of Labor, Education, and Commerce in the spring of 1988 (42:4, 13) revealed that the "basic skills gap" between business needs and the qualifications of entry-level workers was widening. Employers in the study were almost unanimous in their concern that these workers were deficient in reading, writing, math, and communication as well as abilities in problem solving, teamwork, initiative, and adaptability. Employers also identified deficiencies in technical skills such as typing with speed and accuracy and working accurately with computers and computerized programs.

Another study of companies revealed that $65 \%$ of their employees had skill deficiencies serious enough to limit advancement; $50 \%$ had serious problems with writing, speaking, and listening skills; and $35 \%$ of the employers were forced to offer remedial programs because employees were unable to follow oral instructions and could not express ideas effectively $(28: 2)$. 
Most new jobs will require workers who have solid skills in written and oral communication, but fewer than one in four new employees will be able to function at those levels (19:101). Still another study by The National Business Education Association indicated that communication and proper work attitudes were lacking in high school graduates (33:16).

More and more businesses are citing problems with finding qualified employees. At Campbell-Mithun Advertising in Minneapolis, the applicant pool is generally below minimum standards in basic skills. The ratio of applicants to those qualifying is 20:1 for secretaries. Michigan Bell reports that of those applying for clerical positions, only 2 of 15 successfully complete all the typing and written tests. In a 1983 Colorado Employability Skills Survey, 60\% of those applying for jobs were rejected because of deficiencies in the application/interview process (42:13).

Estimates are that by the end of this century, $80 \%$ of the work force will be involved directly or indirectly with the collecting, processing, and storing of information and data (38:17). The gaps and deficiencies noted could have several ramifications: 1 ) employers hiring under-qualified workers resulting in inferior products and services; 2) employers seeking qualified workers employed with other firms, driving up wage scales; 3 ) firms spending massive amounts of money in training; or 4) companies exporting jobs elsewhere (42:19). 
General Competencies and Skills Desired by Employers

Studies that have examined the qualities which employers look for in new employees have produced various results. Employers generally want good attitudes toward work, a good foundation of basic skills, and good interpersonal and occupational skills. They are also unanimous in their desire for workers with good verbal and academic skills as these signal trainability, adaptability, and "achievement motivation" (35:10).

Forbes and Miller (14:32) identify the following key competencies employees will need:

1) A sense of purpose and goals enabling one to understand the context in which one works and the objectives of the company as well as the ability to set priorities and think ahead;

2) An ability to service customers successfully and maintain good relationships;

3) Organization and implementation skills including the management of personal and organization timetables and management of tasks and situations; and

4) Management of interdependence in cooperation with others inside and outside of the group and the ability to transfer existing knowledge and skills to new and unfamiliar settings. 
The National Alliance of Business suggests adding a Fourth " $R$ " to the traditional three $R^{\prime} s$ of reading, writing and arithmetic. They define this " $R$ " as workforce Readiness which includes reasoning, analytical, creative, and problem-solving skills, and behaviors such as reliability, responsibility, and responsiveness to new work requirements $(32: 1)$.

Productive workers today must be able to think creatively, be flexible and adaptable, and be involved in learning new approaches. They must have a broad understanding of the world, ability to handle change, and skills and values for complex, wise and ethical decisions $(43: 3)$.

Employers are also seeking individuals who are able to work with less supervision while making crucial decisions. Abilities in negotiating, resolving conflicts, and working in teams are also mentioned as well as the ability to learn $(8: 29)$. Business wants people, in effect, who have the basics, are adaptable, and have learned to learn!

All of the aforementioned attributes are reaffirmed by other studies completed by Crain (11:3); Baxter and Young (3:95); the National Research Council (36:7); Hazler and Latto (17:133); and Junge $(21: 141-3)$.

Employers surveyed by the Washington State Commission for Vocational Education strongly believe that basic skills and positive work attitudes are the fundamental competencies needed by high school graduates $(44: 12)$. Although employers consider 
vocational education to be an important competency ( 71 percent), it is not regarded as a relatively high priority. Ninety-seven percent felt strongly that vocational education courses should be taught within the context of "employability," emphasizing basic skills, positive work habits, attitudes, and adaptability $(39: 16)$.

Secretarial Skills Desired

Fewer studies were found dealing with specific secretarial skill requirements. Ellyn Dickmann (12:34), in a 1989 survey of Colorado businesses, found the top five entry-level general office skills were spelling/grammar/punctuation, human relations, proofreading, ability to operate general office machines, and records/file management. The top five entry-level computer skills were keyboarding/typing accuracy; word processing; keyboarding/typing speed; personal computer operating systems; and dictation machine operation skills while typing on a word processor.

Modlin (28:8) also found machine transcription to be important with emphasis concentrated on listening, language arts, and transcription skills. Competencies in a course would include all the above skills as well as formatting and editing of documents.

In the past few years, computer literacy has become an important area, although definitions of it vary. In a survey completed in March of 1986, it was found to include various 
topics such as word processing, keyboarding, programming, computer history, and ethics (20:12). Many educators feel that an understanding of computer technology should be considered a basic skill. Because the computer is a tool and not an end in itself, Kearsley believes the most important principle of training is that the computer be taught in the context of actual job tasks (23:14). Thus, applications would be integrated into the mainstream of regular job-related training rather than in isolated courses.

In data processing, students should have a strong foundation in typing and ten-key adding machine skills (10.204). Additional qualifications looked for in these employees include basic clerical skills and skills in bookkeeping, filing, business math, and basic business procedures (10:204).

Research in word processing has clustered around three areas. The first area involves identification of skills needed for success. Chaney found in her survey of $111 \mathrm{firms}$ in Memphis, Tennessee that business was requiring keyboarding skills of 51-60 words per minute for entrance into the field (9:4). Kozlowski states, however, that companies have lowered their standards for typing. A speed of 55 to 60 wpm was once required. Companies will now accept anyone who passes a test between 45 to $50 \mathrm{wpm}$ (24:53). While the technical skills including typing and the grammatical and language art skills are vital, the nontechnical or human relations skills such as 
listening, negotiating, interacting, and mediating skills are also mentioned $(40: 18)$. A valuable training experience in this area, according to Kozlowski, would involve a simulated office giving the students experience in the operation of text-editing equipment as well as in-basket exercises, simulated activities, and workflow organizations $(24: 54)$.

The second area highlights other human factors which must be included in the successful implementation of a word-processing program. These include strong motivational and attitudinal levels.

The third level involves training programs themselves. Training should be involved with automation, human factors, and information management/technical skills (40:19).

Modlin, in 1988, $(28: 4)$ found the following applications of personal computers in business:

$\begin{array}{ll}\text { Word processing } & 64 \% \\ \text { Financial analysis } & 53 \% \\ \text { Accounting } & 38 \% \\ \text { Data Base Access } & 36 \% \\ \text { Personal recordkeeping } & 31 \% \\ \text { Graphics } & 22 \% \\ \text { Games } & 21 \% \\ \text { Engineering/Scientific } & 20 \%\end{array}$

Another study completed in Arkansas involved accounting, legal, and medical firms and showed significant relationships 
between the type of firms and software application. Legal firms predominantly used word processing; accounting firms used accounting packages; and medical firms utilized data management programs $(25: 42)$.

Dockter, too, found that accounting, file management, and word processing are the most used programs in business (13:64).

Personal computers have become the most popular type of equipment used in offices. Lehman found in her 1986 study that 32 percent of the firms currently owned personal computers and approximately 40 percent planned to purchase them within the next year (25:41). While forty different brands of personal computers were used, IBM was the most popular followed by TRS-80 and Apple. Other studies have also revealed IBM to be the industry leader. They reportedly own 74 percent of the market; Apple follows with 6 percent $(27: 42)$.

The most controversial area of entry-level requirements appears to be shorthand. In a study of five large cities along the east and south coast areas, shorthand as an entry-level business requirement varied from one city with 11 percent to another with 72 percent. No firms required shorthand under 80 wpm; 56 percent required 80-90 wpm; 18 percent required 91-100 wpm; and no firms required over 100 wpm. Over half of the companies (52 percent) required no shorthand (45:137-139).

In one study of 50 companies conducted by Harry Moon in 1984, the primary secretarial skills of keyboarding, word 
processing, language skills, and working cooperatively were mentioned as important by all. Of the 50 companies, however, secretaries in only 9 of the companies (18 percent) used shorthand (29:7). Another study of employment agencies revealed shorthand to be as valuable as in the past $(18: 23)$.

Two other articles mention shorthand for high-paying or administrative jobs. Kaylor stated that it is a "definite plus" and a requirement of many employers for a higher-paying secretarial position $(22: 23)$. Murranka acknowledges that while technology has changed many secretarial duties, administrative secretaries continue to take and transcribe shorthand (30:17).

Nancy Groneman points out four reasons to discontinue offering shorthand in education. There is a decrease in jobs requiring it and $a$ decrease in enrollment in schools. Additionally, it is associated with low productivity and high costs. Some businesses use shorthand as a screening device but never require its use on the job. Since all employment tests are required by law to contain content validity, this practice is illegal. Groneman believes if schools, then, offer shorthand knowing this practice exists, they are in essence condoning an illegal hiring practice $(15: 8)$.

In conclusion, the four factors found to be required at entry-level which are then used also in promotion include:

1) Communication: written, oral, telephone skills, reading, following directions, proofreading, vocabulary, and spelling; 
2) Attitude: prompt, loyal, cooperative, pleasant, and capable of retaining confidentiality, working as a team, and possessing a sense of humor;

3) Keyboarding: inputting of alphabetic and numeric data on a computer terminal at 25 wpm. ; and

4) Typewriting: 60 or more wpm with a high degree of accuracy $(28: 6)$.

\section{$\underline{\text { Summary }}$}

The traditional office began to change in 1971 with the advent of the microprocessor. As technology advanced, roles of workers and organizational structures rapidly began to change. Literature is filled with articles about the "office of the future". The accelerating pace of change has had vast implications for future workplaces and for entry-level workers.

Labor market changes require flexible and adaptable employees. Because technology continues to change, the office can no longer be taken for granted. Job requirements and a more complex way of life demand that we move thinking capabilities to higher quantitative and qualitative levels. Emphasis must be placed on processing, interacting, and problem solving enabling students to transfer their skills, knowledge, and attitudes from the classroom to the workplace. Students must know how to learn, collaborate, and be flexible in order to have freedom of choice 
and the potential of economic prosperity. Liberal and technical arenas are no longer separate entities; they must converge in order to meet the demands of society in ways that are relevant, appropriate, and accountable. 


\section{CHAPTER III \\ PROCEDURES AND METHODS}

\section{Methodology}

The first step of the study was to design a questionnaire which would yield results applicable to the problem. In a meeting of the Business and Office Advisory Committee and the business education instructors in the school district, members and teachers submitted questions for use in the survey of Clark County businesses. As the district was targeting 1990 as a year of curriculum review and equipment update, questions regarding specific skill requirements and computer usage were included.

Once the survey was designed, the Advisory Committee members were used to pilot the instrument. They participated in the editing and revision of the questionnaire by writing recommendations regarding instruction clarity. The questionnaire was revised and then approved at another meeting of the Advisory Committee.

\section{Subject Selection}

The 1989 Greater Vancouver Chamber of Commerce Directory was utilized to select participants for this study. The Chamber of 
Commerce is a voluntary alliance of businesses, professionals, and organizations. All the businesses listed under the categories in Table 1 were used in this study. The six categories were chosen because the Advisory Committee felt firms in these categories had the highest percentage of office workers.

TABLE 1

SAMPLE SELECTION OF FIRMS

\begin{tabular}{lcc}
\multicolumn{1}{c}{$\begin{array}{c}\text { Type of Firm } \\
\text { Financial and Investment }\end{array}$} & $\begin{array}{c}\text { Number } \\
\text { of Firms }\end{array}$ & $\begin{array}{c}\text { Percentage } \\
\text { of Total }\end{array}$ \\
Government & 21 & 13.1 \\
Insurance & 8 & 5.0 \\
Legal & 28 & 17.5 \\
Medical & 27 & 16.8 \\
Real Estate & 30 & 18.8 \\
$\quad$ & 46 & 28.8 \\
$\quad$ TOTAL & 160 & 100.0 \\
\hline
\end{tabular}

When the subject selection was completed, each of the 160

firms was telephoned. The individual in the company responsible for hiring entry-level secretarial/clerical employees was asked to assist in the study. All of the individuals agreed to participate in the study. Addresses of companies were confirmed.

Questionnaire Design

A cover letter was sent with each questionnaire to the individual in the company who agreed to assist in the study. The 
letter explained the importance of the study in evaluating curriculum as well as the preparation of qualified employees for the firm.

The questionnaire (Appendix B) contained eight questions. Respondents were asked to check the type of industry which best described the companies and the number of clerical/secretarial employees employed. Three questions regarding hardware and software usage were asked. One question asked respondents to check, on a Likert scale, the competencies and specific technical and vocational skills required of applicants. The scale was a five-point scale; "strongly agree" was given a value of 5; "strongly disagree" a value of 1. Two open-ended questions were used to encourage participants to respond. These questions asked for information processing system changes anticipated in the next five years and the one deficiency perceived as most common in entry-level employees. Survey participants were further encouraged to respond as they were given the opportunity to receive survey results upon completion of the study.

A stamped and self-addressed envelope was enclosed for convenience in returning the questionnaire. Envelopes were coded to identify those returned, classify the firm as to industry type, and maintain confidentiality. 
Treatment of Data

After the data was collected, responses were tabulated on a percentage basis. Mean scores were used for purposes of reporting. Question six on the questionnaire used a Likert scale with values assigned. Five points were assigned for "strongly agree", four points for "agree", three points for "no opinion", two points for "disagree" and one point for "strongly disagree". Tables and information explain the responses to individual questions. 
CHAPTER IV

FINDINGS

Questionnaires were mailed to 160 Clark County businesses to identify entry-level skills and competencies required and determine the utilization of hardware and software applications. of the 160 questionnaires mailed, 125 were returned for a response rate of 78.1 percent. Table 2 shows the questionnaires mailed and returned by industry type.

TABLE 2

QUESTIONNAIRE RETURNS BY INDUSTRY

Type of Firm

Financial and Investment Government Insurance

Legal

Medical

Real Estate

Total

Rate of Return $=78.1 \%$
Questionnaires

Mailed

21

8

28

27

30

$\underline{46}$

160
Questionnaires Returned

17

8

24

21

22

33

125

\section{Analysis of Response}

The response rate depicted above is exceptionally good when compared to other studies. Best reports that a response rate of 50 percent is adequate, 60 percent good, and 70 percent very good $(4: 178)$. Because of the high rate of return on the original mailing, no follow-up was used. 
Questionnaire Items and Findings

Question \#I

Please check the industry which best describes your company:

( ) Financial, Investment

( ) Government

( ) Insurance

( ) Legal

( ) Medical

( ) Real Estate

( ) Other

of the 125 questionnaires returned, 17 were financial and investment businesses, 8 were government, 24 were insurance, 21 were legal, 22 were medical, and 33 were real estate. This resulted in the following percentages of the total respectively: $13.6 \%, 6.4 \%, 19.2 \%, 16.8 \%, 17.6 \%$, and $26.4 \%$. Table 3 shows the frequency and percentage of responses by industry.

TABLE 3

RESPONSES BY INDUSTRY

$\begin{array}{lcr}\text { Type of Firm } & \text { Frequency } & \text { Percent } \\ \text { Financial } & 17 & 13.6 \\ \text { Government } & 8 & 6.4 \\ \text { Insurance } & 24 & 19.2 \\ \text { Legal } & 21 & 16.8 \\ \text { Medical } & 22 & 17.6 \\ \text { Real Estate } & 33 & 26.4 \\ & & 100.0 \\ \text { TOTAL } & 125 & \end{array}$


Check the number of clerical/secretarial employees in your company:

() none
() $1-5$
() $6-10$
() $11-15$

$$
\begin{aligned}
& \text { () } 16-21 \\
& \text { () } 21-30 \\
& \text { () over } 30
\end{aligned}
$$

One-hundred twenty-four firms responded to this question. The mean number of clerical/secretarial employees was 2.7 per firm. Over half the firms (57.3\%) employed between 1 and 5 secretarial workers while 15 (12.1\%) had no secretarial employees. Table 4 shows the number of clerical/secretarial employees employed in the firms questioned.

TABLE 4

CLERICAL/SECRETARIAL EMPLOYEES IN FIRMS

$\begin{array}{ccc}\text { Number of Employees } & \text { Frequency } & \text { Percent } \\ \text { None } & 15 & 12.1 \\ 1-5 & 71 & 57.3 \\ 6-10 & 16 & 12.9 \\ 11-15 & 5 & 4.0 \\ 16-20 & 2 & 1.6 \\ 21-30 & 9 & 7.3 \\ \text { Over 30 } & 6 & 4.8 \\ \text { (Missing) } & 1 & -10 \\ \text { TOTAL } & & 125\end{array}$


QUESTION \#3

Indicate the brand/model of computers currently used in your company and those you plan to purchase. Check all that apply.

$\frac{\text { Now Own }}{(\swarrow)}$

$\frac{\text { Plan to Purchase }}{(\swarrow)}$

Brand/Model

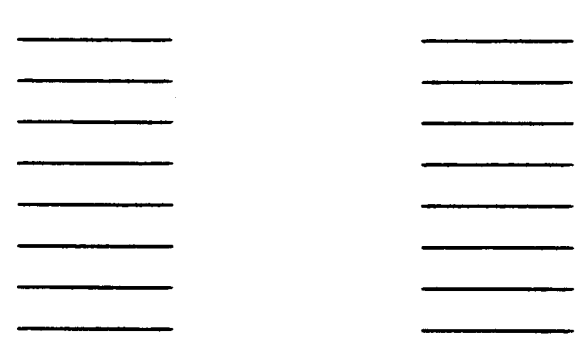

Apple

Compaq

Hewlett/Packard

IBM

Radio Shack

Wang

Other, please specify

Other, please specify

Respondents were given blanks to write in brands and models they now owned. There were 160 responses to this part of the question. The largest response of all categories was for "other". The variety of brand names was large, as shown in Appendix C. Of the 6 brands/models listed, a majority (30.6\%) own IBM computers. Table 5 depicts the brands and models companies own.

\begin{tabular}{lrr}
\multicolumn{1}{c}{ Brand/Model } & Count & Percent \\
\cline { 2 - 3 } Apple & 9 & 5.6 \\
Compaq & 14 & 8.8 \\
Hewlett/Packard & 10 & 6.3 \\
IBM & 49 & 30.6 \\
Radio Shack & 6 & 3.8 \\
Wang & 5 & 3.1 \\
Other & 67 & 41.9 \\
$\quad$ TOTAL & 160 & 100.0
\end{tabular}


The second part of this question asked companies to check or name the brands of computers they planned to purchase. While only 18 percent of the firms responded that they plan to add computers, the majority $(47.8 \%)$ of those plan to purchase IBMs. In the "other" category, brands listed were AST, AT\&T, IBM Compatibles, and Prime. Table 6 shows the count and percent of brands/models firms plan to purchase.

TABLE 6

COMPUTERS BUSINESS PLAN TO PURCHASE

Brand/Model

Apple

Compaq

Hewlett/Packard

IBM

Radio Shack

Other

TOTAL $\underline{\text { Count }}$

1

3

1

11

1

6

23
Percent

4.3

13.0

4.3

47.8

4.3

26.1

100.0

\section{QUESTION \#4}

Indicate the types of software programs you own or plan to purchase. Provide the brand name of the program if possible:

Now Plan to

$\frac{\text { Own }}{(\sqrt{ })} \quad \frac{\text { Purchase }}{(\checkmark)}$ Type of Software

Brand Name

Accounting/bookkeeping

Custom (to your industry)

Desktop publishing

Electronic spreadsheet

Graphics

Marketing

Proofreading/spelling

Records control

Word processing

Other

other

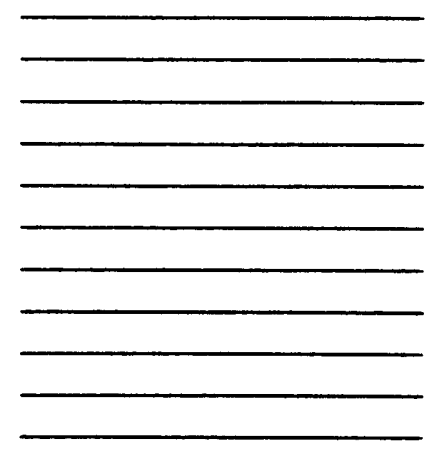


This question asked types of software now used and types of software companies plan to purchase. Word processing packages were used by the most firms with 82 respondents $(66.0 \%)$ using some form of word processing software. A total of 72 responses were recorded for custom software. Most of the custom software users were in the real estate and insurance fields. Sixteen companies use other software as listed in Appendix D. Table 7 shows the count and percent of total software usage.

TABLE 7

SOFTWARE BUSINESSES PRESENTLY USE

\begin{tabular}{|c|c|c|}
\hline Software & Count & Percent \\
\hline Accounting & 57 & 14.3 \\
\hline Custom & 72 & 18.0 \\
\hline Desktop Publishing & 21 & 5.3 \\
\hline Spreadsheet & 40 & 10.0 \\
\hline Graphics & 25 & 6.3 \\
\hline Marketing & 18 & 4.5 \\
\hline Proofreading & 41 & 10.3 \\
\hline Records Control & 28 & 7.0 \\
\hline Word Processing & 82 & 20.5 \\
\hline Other & 16 & 4.0 \\
\hline TOTAL & 400 & 100.0 \\
\hline
\end{tabular}

The variety of brand names of software used was immense. Appendix $E$ contains a listing of the brand names firms now use in each of the categories in the table above. The most common programs were Word Perfect and Word Perfect 5.0 (29 listings) and Lotus 1-2-3 (18 listings). 
This question also asked the types of software firms plan to purchase. The 58 total responses from 23 companies did not favor any particular area. Table 8 represents the frequency and percent of responses for the software businesses plan to purchase. Only eight of the companies listed the brand names of the programs they plan to purchase. Appendix $F$ lists those software programs companies plan to purchase.

\section{TABLE 8}

SOFTWARE BUSINESSES PLAN TO PURCHASE

\begin{tabular}{lcc}
\multicolumn{1}{c}{ Software } & Count & Percent \\
\cline { 2 - 3 } Accounting & 9 & 15.5 \\
Custom & 8 & 13.8 \\
Desktop Publishing & 6 & 10.3 \\
Spreadsheet & 6 & 10.3 \\
Graphics & 4 & 6.9 \\
Marketing & 3 & 5.2 \\
Proofreading & 6 & 10.3 \\
Records Control & 4 & 6.9 \\
Word Processing & 7 & 12.1 \\
Other & 5 & -8.6 \\
$\quad$ TOTAL & 58 & 100.0 \\
\hline
\end{tabular}

\section{QUESTION \#5}

To what extent is your company using a networked system?

( ) Most/all of the time

( ) Approximately $50 \%$ of the time

( ) Rarely/not at all

Table 9 shows the frequency with which companies used a networked system. One-third of all respondents used a networked system most of the time while one-sixth used it about 50 percent 
of the time. More than half of the firms either used a networked system rarely or not at all or did not answer the question.

TABLE 9

COMPANIES USING A NETWORKED SYSTEM

$\begin{array}{lcc}\text { Usage Extent. } & \text { Frequency } & \begin{array}{c}\text { Valid } \\ \text { Percent }\end{array} \\ \text { Most of the time } & 42 & 36.5 \\ \text { About } 50 \% \text { of the time } & 19 & 16.5 \\ \text { Rarely/not at all } & 54 & 47.0 \\ \text { (No response) } & 10 & - \\ \text { TOTAL } & 125 & 100.0\end{array}$

QUESTION \#6

Indicate the degree to which you agree with the statements below using the following scale:

5 = Strongly Agree

4 = Agree

3 = No Opinion

$2=$ Disagree

1 = Strong Disagree

A. "It is very important for my company to hire high school graduates with the following competencies:"

(5) (4) (3) (2) (1)

$(d) \quad(d) \quad(d) \quad(d) \quad(n)$

Basic math and science skills

Interpersonal skills/human relations Written/oral communication

Positive work habits and attitudes

Reasoning and problem-solving skills

Specific technical/vocational skills

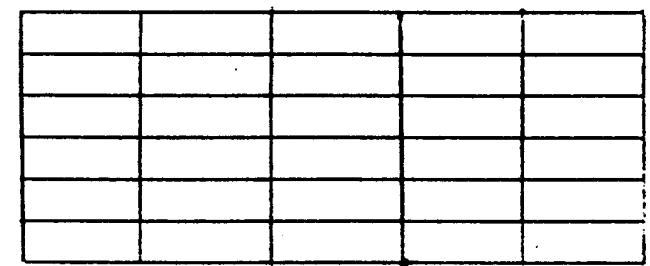

Basic Math and Science Skills

Most companies ( $89.5 \%)$ either "agreed" or "strongly agreed" with Question 6 (mean of 4.33). Only five firms "disagreed" or "strongly disagreed". Seven had "no opinion". Ten firms did not 
answer. Table 10 indicates how respondents valued basic math and science skills.

TABLE 10

IMPORTANCE OF BASIC MATH AND SCIENCE SKILLS

Valid

Value Label

Frequency

Percent

Strongly Disagree

0

Disagree

No Opinion

Agree

Strongly Agree

(No response)

5

7

48

55

10

.0

4.3

6.1

41.7

47.8

TOTAL

125

100.0

\section{Interpersonal Skills/Human Relations}

Table 11 depicts how respondents valued interpersonal skills Nearly three-fourths $(75.8 \%)$ of the firms who responded "strongly agreed" with this statement while one-fifth $(20.8 \%)$ "agreed". Two firms "disagreed", two had "no opinion", and five did not respond. The mean was 4.71 .

TABLE 11

IMPORTANCE OF INTERPERSONAL/HUMAN RELATIONS SKILLS

\begin{tabular}{lcc} 
Value Label & Frequency & $\begin{array}{c}\text { Valid } \\
\text { Percent }\end{array}$ \\
Strongly Disagree & 0 & .0 \\
Disagree & 2 & 1.7 \\
No Opinion & 2 & 1.7 \\
Agree & 25 & 20.8 \\
Strongly Agree & 91 & 75.8 \\
(No response) & 5 & - \\
$\quad$ TOTAL & 125 & 100.0 \\
\hline
\end{tabular}


Written/Oral Communication

Table 12 depicts the answers to how important it was to firms to hire graduates with written and oral communication competencies. Over four-fifths (83.6\%) of the firms "strongly agreed" while another 13.9\% "agreed" totaling 97 percent agreement with the communication statement. The mean was 4.81 . While no firms responded reflecting disagreement, 3 firms had no opinion and 3 firms failed to respond.

TABLE 12

IMPORTANCE OF WRITTEN/ORAL COMMUNICATION SKILLS

\begin{tabular}{lcc} 
Value Label & Frequency & $\begin{array}{c}\text { Valid } \\
\text { Percent }\end{array}$ \\
Strongly Disagree & 0 & .0 \\
Disagree & 0 & .0 \\
No Opinion & 3 & 2.5 \\
Agree & 17 & 13.9 \\
Strongly Agree & 102 & 83.6 \\
(No response) & 3 & -- \\
TOTAL & 125 & 100.0 \\
\hline
\end{tabular}

\section{Positive Work Habits and Attitudes}

Table 13 illustrates the value of positive work habits and attitudes to firms who hire high school graduates. Other than the three firms who did not respond, all the other 122 either "agreed" (4.9\%) or "strongly agreed" (95.1\%). The mean was 4.95 . 
TABLE 13

IMPORTANCE OF POSITIVE WORK HABITS AND ATTITUDES

$\begin{array}{lcc}\text { Value Label } & \text { Frequency } & \begin{array}{c}\text { Valid } \\ \text { Percent }\end{array} \\ \text { Strongly Disagree } & 0 & .0 \\ \text { Disagree } & 0 & .0 \\ \text { No Opinion } & 0 & .0 \\ \text { Agree } & 6 & 4.9 \\ \text { Strongly Agree } & 116 & 95.1 \\ \text { (No response) } & 3 & -. \\ \text { Total } & 125 & 100.0\end{array}$

Reasoning and Problem-Solving Skills

Table 14 depicts how respondents valued reasoning and problem-solving skills. Over three-fourths (76.0\%) "strongly agreed" while almost one-fourth (24.0\%) "agreed" leaving only four firms who did not respond. The mean was 4.76 .

TABLE 14 IMPORTANCE OF REASONING AND PROBLEM-SOLVING SKILLS

$\begin{array}{lcc}\text { Value Label } & \text { Frequency } & \begin{array}{c}\text { Valid } \\ \text { Percent }\end{array} \\ \text { Strongly Disagree } & 0 & .0 \\ \text { Disagree } & 0 & .0 \\ \text { No Opinion } & 0 & .0 \\ \text { Agree } & 29 & 24.0 \\ \text { Strongly Agree } & 92 & 76.0 \\ \text { (No response) } & 4 & -. \\ \text { TOTAL } & 125 & 100.0\end{array}$

Specific Technical/Vocational Skills

Table 15 depicts how respondents valued specific technical and vocational skills. 
Eighty-seven of the 120 firms who responded either "agreed" $(42.5 \%)$ or "strongly agreed" (30.8\%). Only five percent "disagreed". The mean was 3.96 .

TABLE 15

IMPORTANCE OF SPECIFIC TECHNICAL/VOCATIONAL SKILLS

$\begin{array}{lcc}\text { Value Label } & \text { Frequency } & \begin{array}{c}\text { Valid } \\ \text { Percent }\end{array} \\ \text { Strongly Disagree } & 3 & 2.5 \\ \text { Disagree } & 4 & 3.3 \\ \text { No Opinion } & 25 & 20.8 \\ \text { Agree } & 51 & 42.5 \\ \text { Strongly Agree } & 37 & 30.8 \\ \text { (No response) } & 5 & - \\ \text { TOTAL } & 125 & 100.0\end{array}$

All six of the competencies listed in question 6 , part $A$, above were responded to favorably. The competencies recorded as important competencies of high school graduates are arranged below by descending mean score values.

TABLE 16

IMPORTANT COMPETENCIES OF HIGH SCHOOL GRADUATES

\section{Competency}

Positive Work Habits and Attitudes Written/Oral Communication Reasoning and Problem-Solving Skills Interpersonal/Human Relations Skills Basic Math and Science Skills Specific Technical/Vocational Skills
Mean Score

4.95

4.81

4.76

4.71

4.33

3.96 


\section{QUESTION \#6 (PART B)}

B. "It is very important for my company to hire high school Eraduates with the following specific technical or vocational skills:"

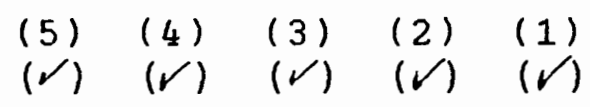

Accounting/bookkeeping

Desktop publishing

Dictation/transcription equipment

Electronic calculator

General office machines

Keyboarding/typing accuracy

Keyboarding/typing speed of 25-50 wpm

Keyboarding/typing speed of $50+$ wpm

Personal computer operating systems,

spreadsheet, and data base

Proofreading

Shorthand

Spelling/grammar/punctuation

Telephone techniques

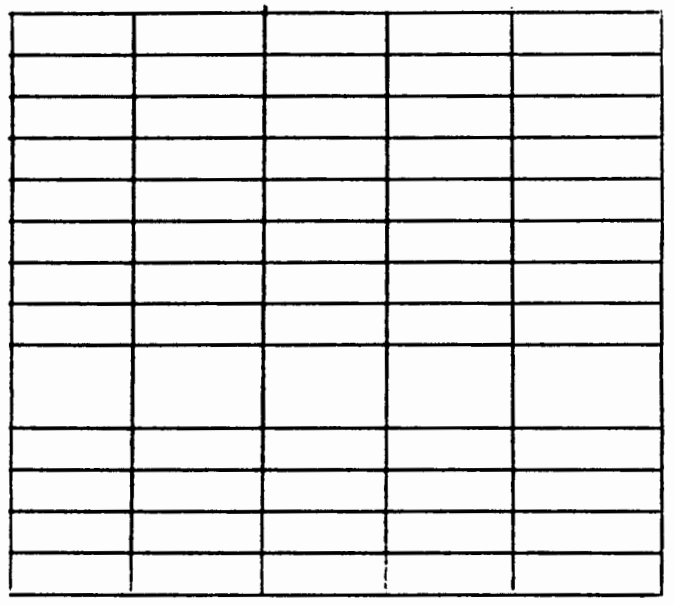

Accounting/Bookkeeping

Table

17 indicates

how

respondents

valued

accounting/bookkeeping skills. of those who responded, $11.8 \%$ "disagreed" or "strongly disagreed" while $61.8 \%$ "agreed" or "strongly agreed". The mean was 3.71 .

TABLE 17

IMPORTANCE OF ACCOUNTING/BOOKKEEPING SKILLS

\begin{tabular}{lcc}
\multicolumn{1}{c}{ Value Label } & Frequency & $\begin{array}{c}\text { Valid } \\
\text { Percent }\end{array}$ \\
Strongly Disagree & 2 & 1.8 \\
Disagree & 11 & 10.0 \\
No Opinion & 29 & 26.4 \\
Agree & 43 & 39.1 \\
Strongly Agree & 25 & 22.7 \\
(No response) & 15 & -- \\
$\quad$ TOTAL & 125 & 100.0
\end{tabular}




\section{Desktop Publishing}

Table 18 depicts how respondents valued desktop publishing. Of those who responded, the largest percentage $(40.0 \%)$ had "no opinion". While $38.1 \%$ "agreed" or "strongly agreed", $21.9 \%$ "disagreed" or "strongly disagreed". The mean was 3.23 .

\section{TABLE 18}

IMPORTANCE OF DESKTOP PUBLISHING

\begin{tabular}{lcc}
\multicolumn{1}{c}{ Value Label } & Frequency & $\begin{array}{c}\text { Valid } \\
\text { Percent }\end{array}$ \\
Strongly Disagree & 6 & 5.7 \\
Disagree & 17 & 16.2 \\
No Opinion & 42 & 40.0 \\
Agree & 27 & 25.7 \\
Strongly Agree & 13 & 12.4 \\
(No response) & 20 & -- \\
$\quad$ TOTAL & 125 & 100.0
\end{tabular}

Dictation/Transcription Equipment

Table 19 represents responses to the importance of high school graduates having dictation/transcription skills. of those who responded, the largest percentage (40\%) had "no opinion". One-fifth (19.8\%) "agreed" and one-fifth (20.7\%) "strongly agreed". Nearly one-fifth (19.8\%) "disagreed" and "strongly disagreed". The mean score was 3.34 . 
TABLE 19

IMPORTANCE OF DICTATION/TRANSCRIPTION SKILLS

\begin{tabular}{lcc} 
Value Label & Frequency & $\begin{array}{c}\text { Valid } \\
\text { Percent }\end{array}$ \\
Strongly Disagree & 8 & 7.2 \\
Disagree & 14 & 12.6 \\
No Opinion & 44 & 39.6 \\
Agree & 22 & 19.8 \\
Strongly Agree & 23 & 20.7 \\
(No response) & 14 & - \\
$\quad$ TOTAL & 125 & 100.0 \\
\hline
\end{tabular}

Electronic Calculator

Table 20 depicts how respondents valued electronic calculator skills. Of the 117 firms who responded, only 8 firms (6.8\%) "disagreed" while $80.3 \%$ "agreed" and "strongly agreed". The mean score was 4.13 .

TABLE 20

IMPORTANCE OF ELECTRONIC CALCULATOR SKILLS

\begin{tabular}{lcc} 
Value Label & Frequency & $\begin{array}{c}\text { Valid } \\
\text { Percent }\end{array}$ \\
Strongly Disagree & 0 & .0 \\
Disagree & 8 & 6.8 \\
No Opinion & 15 & 12.8 \\
Agree & 48 & 41.0 \\
Strongly Agree & 46 & 39.3 \\
(No response) & -8 & -- \\
$\quad$ TOTAL & 125 & 100.0 \\
\hline
\end{tabular}


General Office Machines

Table 21 depicts how respondents valued general office machine skills. Of those who responded, nearly 90 percent "agreed" and "strongly agreed". Less than one percent "disagreed" while 10.3 percent had "no opinion". The mean score was 4.33 .

\begin{tabular}{lcc}
\multicolumn{1}{c}{ Value Label } & Frequency & $\begin{array}{c}\text { Valid } \\
\text { Percent }\end{array}$ \\
Strongly Disagree & 0 & .0 \\
Disagree & 2 & .9 \\
No Opinion & 12 & 10.3 \\
Agree & 51 & 43.6 \\
Strongly Agree & 53 & 45.3 \\
(No response) & -8 & - \\
$\quad$ TOTAL & 125 & 100.0 \\
\hline
\end{tabular}

Keyboarding/Typing Accuracy

Table 22 represents the answers to the question of the importance of keyboarding accuracy to companies. Over ninetenths of those who responded "agreed" (26.5\%) or "strongly agreed" (66.7\%). Only 1.7\% "disagreed" and 5.1\% had "no opinion". The mean score was 4.58 . 
TABLE 22

IMPORTANCE OF KEYBOARDING/TYPING ACCURACY

\begin{tabular}{|c|c|c|}
\hline Value Label & Frequency & $\begin{array}{l}\text { Valid } \\
\text { Percent }\end{array}$ \\
\hline $\begin{array}{l}\text { Strongly Disagree } \\
\text { Disagree } \\
\text { No Opinion } \\
\text { Agree } \\
\text { Strongly Agree } \\
\text { (No response) }\end{array}$ & $\begin{array}{r}0 \\
2 \\
6 \\
31 \\
78 \\
8 \\
\end{array}$ & $\begin{array}{r}.0 \\
1.7 \\
5.1 \\
26.5 \\
66.7 \\
-- \\
\end{array}$ \\
\hline TOTAL & 125 & 100.0 \\
\hline
\end{tabular}

Keyboarding/Typing Speed of $25-50$ wpm

Table 23 depicts how respondents valued keyboarding speeds of 25 to 50 words per minute. Of the 106 firms who responded, $31(29.2 \%)$ "agreed" and 31 (29.2\%) "strongly agreed". Fifteen companies (14.2\%) "disagreed" and $\operatorname{six}(5.7 \%)$ "strongly disagreed". The mean score was 3.62 . In reviewing the above table, one can see that accuracy was far more important to companies than speeds in this range.

\section{TABLE 23}

IMPORTANCE OF KEYBOARDING/TYPING SPEEDS OF 25-50 WPM

\begin{tabular}{lcc}
\multicolumn{1}{c}{ Value Label } & Frequency & $\begin{array}{c}\text { Valid } \\
\text { Percent }\end{array}$ \\
Strongly Disagree & 6 & 5.7 \\
Disagree & 15 & 14.2 \\
No Opinion & 23 & 21.7 \\
Agree & 31 & 29.2 \\
Strongly Agree & 31 & 29.2 \\
(No response) & 19 & - \\
$\quad$ TOTAL & 125 & 100.0 \\
\hline
\end{tabular}


Keyboarding/Typing Speed of $50+$ wpm

Table 24 depicts how respondents valued over 50 wpm keyboarding speed skills. Of those who responded, 74 firms (66.6\%) "agreed" and "strongly agreed". Only 18 firms (16.2\%) "disagreed". The mean score was 3.85 .

$\begin{array}{lcc}\text { Value Label } & \text { Frequency } & \begin{array}{c}\text { Valid } \\ \text { Percent }\end{array} \\ \text { Strongly Disagree } & 5 & 4.5 \\ \text { Disagree } & 13 & 11.7 \\ \text { No Opinion } & 19 & 17.1 \\ \text { Agree } & 31 & 27.9 \\ \text { Strongly Agree } & 43 & 38.7 \\ \text { (No response) } & 14 & - \\ \text { TOTAL } & 125 & 100.0\end{array}$

Personal Computer Operating Systems, Spreadsheet, and Data Base

Table 25 depicts how respondents valued personal operating systems, spreadsheet, and data base skills. Nearly threefourths $(71.6 \%)$ of those who responded "agreed". Less than onetenth (8.9\%) of those who responded "disagreed". Almost onefifth (19.5\%) had "no opinion". The mean score was 3.95 . 
TABLE 25

IMPORTANCE OF COMPUTER OPERATING SYSTEM, SPREADSHEET, AND DATA BASE SKILLS

\section{Value Label}

Strongly Disagree

Disagree

No Opinion

Agree

Strongly Agree

(No response)

\section{Frequency \\ Valid \\ Percent}

1

22

44

37

12

125

$$
\begin{array}{r}
.9 \\
8.0 \\
19.5 \\
38.9 \\
32.7 \\
-- \\
\hline 100.0
\end{array}
$$

\section{Proofreading}

Table 26 depicts how respondents valued proofreading skills. of the 116 firms who responded, over four-fifths $(80.2 \%)$ "agreed" and less than one-tenth (6.9\%) "disagreed". The mean score was 4.22 .

\begin{tabular}{lcc} 
Value Label & Frequency & $\begin{array}{c}\text { Valid } \\
\text { Percent }\end{array}$ \\
Strongly Disagree & 3 & 2.6 \\
Disagree & 5 & 4.3 \\
No Opinion & 15 & 12.9 \\
Agree & 34 & 29.3 \\
Strongly Agree & 59 & 50.9 \\
(No response) & 9 & -- \\
$\quad$ TOTAL & 125 & 100.0 \\
\hline
\end{tabular}


Shorthand

Table 27 depicts how respondents valued shorthand skills. of the 109 firms who responded, nearly one-half (47.8\%) "disagreed" and approximately one-tenth (11.9\%) "agreed". The mean score was 2.42 .

\begin{tabular}{lcc}
\multicolumn{1}{c}{ Value Label } & Frequency & $\begin{array}{c}\text { Valid } \\
\text { Percent }\end{array}$ \\
Strongly Disagree & 26 & 23.9 \\
Disagree & 26 & 23.9 \\
No Opinion & 44 & 40.4 \\
Agree & 11 & 10.1 \\
Strongly Agree & 2 & 1.8 \\
(No response) & 16 & -- \\
$\quad$ TOTAL & 125 & 100.0 \\
\hline
\end{tabular}

\section{Spelling/Grammar/Punctuation}

Table 28 depicts how respondents valued spelling, grammar, and punctuation skills. Of the 120 firms who responded to this question, less than one percent $(0.8 \%)$ "disagreed" and three percent had "no opinion". Over 95 percent "agreed". The mean score was 4.63 . 
TABLE 28

IMPORTANCE OF SPELLING/GRAMMAR/PUNCTUATION SKILLS

\begin{tabular}{lcc} 
Value Label & Frequency & $\begin{array}{c}\text { Valid } \\
\text { Percent }\end{array}$ \\
Strongly Disagree & 0 & .0 \\
Disagree & 1 & .8 \\
No Opinion & 4 & 3.3 \\
Agree & 34 & 28.3 \\
Strongly Agree & 81 & 67.5 \\
(No response) & 5 & - \\
TOTAL & 125 & 100.0 \\
\hline
\end{tabular}

Telephone Techniques

Table 29 depicts how respondents valued telephone technique skills. Less than one percent "disagreed" while three percent had "no opinion". The remainder (95.9\%) "agreed". The mean was 4.75 .

TABLE 29

IMPORTANCE OF TELEPHONE TECHNIQUE SKILLS

\begin{tabular}{lcc}
\multicolumn{1}{c}{ Value Label } & Frequency & $\begin{array}{c}\text { Valid } \\
\text { Percent }\end{array}$ \\
Strongly Disagree & 0 & .0 \\
Disagree & 1 & .8 \\
No Opinion & 4 & 3.3 \\
Agree & 20 & 16.4 \\
Strongly Agree & 97 & -19.5 \\
(No response) & 3 & - \\
$\quad$ TOTAL & 125 & 100.0
\end{tabular}

Summary of Technical/Vocational Skill Questions

The overall technical and vocational skills which respondents felt were extremely important included telephone 
techniques,

spelling/grammar/punctuation,

and keyboarding accuracy. The one skill companies did not feel important was shorthand. The technical and vocational skills recorded as important skills of high school graduates are arranged below by descending mean score values.

IMPORTANT TECHNICAL/VOCATIONAL SKILLS

\section{Technical/Vocational Skills}

Telephone Techniques

Spelling/Grammar/Punctuation

Keyboarding/Typing Accuracy

General office Machines

Proofreading

Electronic Calculator

Personal Computer Operating Systems

Keyboarding/Typing Speed of $50+$ wpm

Accounting/Bookkeeping

Keyboarding/Typing Speed of 25-50 wpm

Dictation/Transcription Equipment

Desktop Publishing

Shorthand

\section{Mean Score}

4.75

4.63

4.58

4.33

4.22

4.13

3.95

3.85

3.71

3.62

3.34

3.23

2.42

\section{QUESTION 7}

What changes in your information processing system do you anticipate in the next five years?

The majority of the 82 firms responding mentioned an increase in computerization. Forty-seven listed the upgrading of hardware systems, software packages, and technological advances such as smaller computers with more color, customization, and tracking systems. Ten listed an expansion in networking. Eight 
noted particular programs they would like to expand such as accounting, automatic billing, graphics, word processing, and electronic claim processing. More FAX machines, electronic mail, and interfacing of programs with government agencies were seen as trends. The remainder of the respondents hoped for purchase of their own systems with user-friendly programs.

\section{QUESTION 8}

Complete the following sentence: "The one deficiency perceived as most common in entry-level employees is ."

Table 31 depicts responses given to the question of deficiences in entry-level employees.

TABLE 31

DEFICIENCIES PERCEIVED IN ENTRY-LEVEL EMPLOYEES

\section{Deficiency Cited}

Response

Communication skills Frequency

Work attitudes and habits

Spelling/grammar

22

Training/knowledge/experience

18

14

Motivation/initiative/ambition/pride in achievements 13

Work ethics

Human relations

11

Basic reasoning and common sense

Maturity

7

Professionalism

Basic office skills (keyboarding/filing)

Productivity/efficiency/prioritization of tasks

Self-confidence

Problem-solving skills

Responsibility

Ability to work independently

Appearance

Math skills

Proofreading 


\section{Summary}

Tables 3 through 31 and Appendixes $C$ through $F$ have presented the data collected from the 125 firms responding in this study. Summaries of the information have been provided to (1) identify the entry-level clerical/secretarial skills and competencies required in Clark County businesses; and (2) determine utilitization of microcomputer hardware and software applications . 
CHAPTER V

CONCLUSIONS AND RECOMMENDATIONS

\section{General Information}

The majority of businesses surveyed in the Clark County area are small businesses employing one to five clerical/secretarial workers. Fifteen companies employed no secretaries. The mean number of secretarial employees in business was 2.67 .

Hardware and Software Usage

of the 117 firms who responded to the question regarding current use of computers by the firm, only three firms do not presently use computers. All three plan to purchase them in the future.

of the 45 various brands of computers owned, 49 of the 117 companies, or 42 percent, own IBMs. In addition, nearly half of the firms intending to purchase computers in the future indicated the purchase of IBMs. This shows that in Clark County, as in other parts of the country, IBM is the industry leader. Their nearest competition in this area is Compaq, with 12 percent, followed closely by Hewlett-Packard, Apple, Radio Shack, and Wang .

This study reveals that computers and software are used in a variety of tasks. While 66 percent of the Clark County firms in this study utilize word-processing software, software is also widely used for accounting, spreadsheet, and proofreading 
functions. Over half of the companies, mainly in the real estate industry, use customized software.

There is a tremendous variety in the brands of software used. Companies listed 116 brands used in the nine program areas. Appendix E lists those responses by program area. There seems to be no particular preference, however, for software packages firms plan to purchase. Accounting, custom, and word processing programs all received over 30 percent of the responses, yet only 58 of the 160 companies responded to the question, and only 8 of those companies listed specific names of software packages they intend to purchase.

Networking is not a common feature in Clark County businesses. Nearly half of the firms who responded rarely, if ever, use it. A few firms responded that they did not know what networking was.

\section{Competencies}

Previous studies have examined general competencies that employers look for in new employees. Employers generally wanted good communication skills, positive attitudes, good interpersonal or human relations skills, and a strong foundation in the basic academic areas. While they considered specific vocational education to be an important competency, they felt it should be taught in a framework of "employability" which emphasized basic skills. 
This study is in agreement with previous studies with employers listing important competencies in the following order: positive work habits and attitude; (2) written/oral communication; (3) reasoning and problem-solving skills; (4) interpersonal skills/human relations; and (5) basic math and science skills. Over 80 percent of the responding companies agreed with those responses. Only 70 percent of responding $\mathrm{Clark}$ County businesses felt it important to hire high school graduates with specific technical or vocational skills.

\section{Specific Technical and Vocational Skills}

Specific technical and vocational skills desired were examined in previous studies. Records management, spelling and grammar, proofreading, keyboarding speed and accuracy, word processing, accounting, and dictation machines were all cited. The most controversial area was shorthand with studies quoting between 11 and 72 percent deeming it important.

While telephone techniques was not specifically cited in the previous studies, this study found it to be the most important technical skill desired in hiring high school graduates. The following six all received mean scores above 4 (on a 1-5 scale) and are listed in descending order: telephone techniques, spelling/grammar/punctuation, keyboarding accuracy, general office machines, proofreading, and electronic calculator. 
The only skill receiving less than a mean of 3.0 , with an actual score of 2.4, was shorthand. Although the firms surveyed in this study were not asked if shorthand should be discontinued in our present curriculum, it seems that arguments presented in other studies for discontinuing shorthand are reasonable. The main reasons previously cited in research were a decrease in jobs requiring it and a decrease in enrollment in schools. This study indicates that few firms in Clark County require shorthand.

\section{Deficiencies of Entry-Level Employees}

Research concerning the gap between employer demands and employee skills cited many deficiencies of workers. Although those deficiencies varied, there was agreement that the basic skills of communication, reading, writing, and math, and the competencies of worker attitudes, critical thinking, and problem solving needed improvement. This study concurs with those findings with communication skills receiving the most responses to the question of the most common deficiency perceived in entrylevel workers. Three of the other top four (work attitudes and habits, spelling/grammar/punctuation, and work ethic) were also cited in earlier findings. The lack of training, knowledge, and experience was not mentioned in previous studies, yet received 13 responses to the question of entry-level worker deficiencies in this study. Many entry-level workers may indeed lack training and experience. 
Recommendations

The following recommendations are made based on the data collected from business firms in the clark County area:

1. Clark County public schools should continue offering courses in vocational areas. Courses, however, should be taught emphasizing basic language, communication, and math skills in a context of "employability".

2. Shorthand should be discontinued as a course offering due to a decrease in requirements in business.

3. Schools in the Clark County area should give strong consideration to purchasing IBM in the future. IBM was used by the majority of companies, and companies most often listed IBM as the computer they plan to purchase.

4. Although there is a multitude of software being used, the majority use Lotus $1-2-3$ in electronic- spreadsheet programs and word Perfect in word-processing programs. These should both continue to be integrated in school secretarial programs.

5. Clark County public schools must maintain a close relationship with businesses in the area in order to provide relevant 
career education and train students adequately for entry-level work and success in a changing society.

\section{Summary}

This

study

has

identified

the

entry-level

clerical/secretarial skills and competencies required in $\mathrm{Clark}$ County businesses and has determined the utilization of microcomputer hardware and software applications. With this information, public school educators must review and update curricula in order to meet the needs of the business community. Continued communication with and involvement in the community will provide the link needed to insure success for the students who will be employed in the near future.

The primary responsibility of educators, then, is to provide students with both the technical skills and nontechnical competencies needed for job entry into the office. By fostering closer ties with business, we will foster better education as well. 
REFERENCES CITED

1. Allen, David. "Oregon Careers 1987-88," State of Oregon, Employment Division, February, 1989, p. 111 .

2. Allen, David and Hannum, Jeff. "Oregon Workforce 2000," State of Oregon, Employment Division, June, 1987, p. $1-40$.

3. Baxter, M.B. and Young, J.L.. "What do Employers Expect from High School Graduates," NASSP Bulletin, v. 66, p. 93-98.

4. Best, John W. and Kahn, James V. Research in Education, New Jersey: Prentice-Hall, 1986, p. 178.

5. "Bright Future for Administrative Support Jobs," Office, v. 100, October, 1984, p. 97-98.

6. Brouillet, Frank. Washington's Commitment to Job Training, Office of State Superintendent of Public Instruction, 1986, p. 1-16.

7. Caradonio, James and Spring, William. "The Boston Compact," VocEd, April, 1983, p. 30-31, 43.

8. Carnevale, Anthony P., Gainer, Leila J., Meltzer, Ann S., and Holland, Shari L. "Workplace Basics," AACJC Journal, v. 59, February/March, 1989, p. 28$29,32-33$.

9. Chaney, Lillian H. and Otto, Joe C. "Word Processing Practices and Procedures in Memphis Area Businesses," Mid-South Business Journal, v. 7, January, 1987, p. 3-5.

10. Cicero, John J. Jr. "Data Processing: Basic Concepts and Skills", The Balance Sheet, February, 1981, p. 203-205.

11. Crain, R.L. "The Quality of American High School Graduates: What Personnel Officers Say and Do About It," Report No. 354, Washington, D.C.: National Institute of Education, 1984. 
12. Dickmann, Ellyn M. "Business Surveys Measure Need for Entry-Level Office Skills," The Balance Sheet, v. 70, May/June, 1989, p. 33-35.

13. Dockter, DuWayne L. "Microcomputers in Business; How Are They Being Used?" Journal of Business Education, November, 1984, p. 63-6.

14. Forbes, Sheila and Miller, John. "What Should Employers Ask of the Education System," Personnel Management, March, 1988, p. 32-36.

15. Groneman, Nancy. "The Evolution in Business Education," Business Education Forum, December, 1984 , p. 6-9.

16. Hallett, Jeffrey J. "Worklife Visions," American Society for Personnel Administration, september, 1987 .

17. Hazler, Richard J. and Latto, Lowell D. "Employers' Opinions on the Attitudes and Skills of High School Graduates," Journal of Employment Counseling, v. 24, September, 1987, p. 130-136.

18. Hosler, Mary Margaret. "Employment Agencies Support Shorthand," Business Education World, v. 63, No. 2, November-December, 1982, p. 23.

19. "Human Capital, The Decline of America's Work Force," Business Week, Special Report, September 19, 1988, p. $100-121$.

20. Johnson, Jack E. "Computer Literacy: A Necessity, Not a Luxury," Business Education Forum, December, 1986, p. $12-13$.

21. Junge, Denis A.; Daniels, Harry; and Karmos, Joseph S. "Personnel Managers' Perceptions of Requisite Basic Skills," The Vocational Guidance Quarterly, v. 33, Number 2, December, 1984, p. 130.

22. Kaylor, Diane. "Skill Plusses: Shorthand and Word Processing," Business Education World, v. 63 , November-December, 1982, p. 23.

23. Kearsley, Greg; Hunter, Beverly; and Hillelsohn, Michael. "Computer Literacy in Business and Industry: Three Examples Using Microcomputers," Educational Technology, July, 1982, p. 9-14. 
24. Kozlowski, Paty. "Word Processing: What are Educators Facing Today?" The Balance Sheet, October, 1980, p. $52-56$.

25. Lehman, Carol M. "An Investigation of the Current Practices of Personal Computer Utilization in Accounting, Legal, and Medical Firms with Implications for the Business Education Curriculum," NABTE Review, 1986, p. 21.

26. Lydeen, Jerald B., "Declining Enrollments in Business Education," Business Education Forum, Yearbook Issue, April-May, 1986, p. 46-50.

27. Mason, Janet. "PCs Dig In," Management World, November, 1984, p. 8-10.

28. Modlin, Gail G. Preparing Your Students for the Office in Their Future, Gregg/McGraw-Hill, 1988.

29. Moon, Harry R., "Eliminating Busy Work," The Secretary, April, 1984, p. 7 .

30. Murranka, Patricia. "Has Technology Changed the Role of the Secretary?" NATBE Review, Issue 8, 1981, p. $17-20$.

31. National Alliance of Business. "The Challenge: Now and to the Year 2000," Washington, D.C., 1988.

32. National Alliance of Business. The Fourth R: Workforce Readiness," Washington, D.C., 1988.

33. National Business Education Association. Relevance in the Education of Today's Business Student, Washington, D.C., 1973.

34. National Business Education Association, Public Relations Committee. "Business Education Meets the Needs of the Nation," Business Education Forum, v. 39, October, 1984, p. 3-5.

35. National Center for Research in Vocational Education. "Questions Frequently Asked about Vocational Education," The Ohio State University, Columbus, Ohio, 1987, p. 1-33. 
36. National Research Council. "High Schools and the Changing Workplace: The Employers' View Report of the Panel on Secondary School Education for the Changing Workplace," Report No. 43, Washington, D.C.

37. Newell, Terry. "The Future and Federal Training," Public Personnel Management, v. 17, Fall, 1988, p. 261-271.

38. Oswalt, Beverly Jo. "Identification of Competencies Necessary for Computer Literacy and Determination of Emphasis Placed on Each Competency in Introduction to Data Processing Courses Offered at the High School Level," Doctoral dissertation, Memphis State University, 1982.

38. Turner, Isiah. "The Workforce of the Future, Washington State," Washington State Employment Security Department, November, 1987.

40. U.S. Department of Labor. "Women, Clerical Work, and Office Automation: Issues for Research," Conference Report by the Women's Bureau, 1986, p. $1-64$.

41. U.S. Department of Labor. "Workforce 2000, Work and Workers for the 21st Century," Executive Summary Book, 1987 .

42. U.S. Department of Labor, U.S. Department of Education, and U.S. Department of Commerce. Building a Quality Workforce, July, 1988.

43. Washington Education Association. "Restructuring Public Education: Building a Learning Community," A Report of the Education Task Force, Federal Way, Washington, 1989.

44. Washington State Commission for Vocational Education. Employee Iraining Needs as Expressed by Employers in Washington State, 1987, p. 1-37.

45. Yost, Alan E. "Warning: A Bear Might Be Shaking Your Tree," Journal of Career Planning \& Employment, v. 46-47, 1985-87, p. 29-32. 


\section{REFERENCES NOT CITED}

1. Bell, Terrel. "We Must Be A Nation of Learners," USA Today, November 18, 1986. Found in AACJC, v. 59, February/March, 1989, P. 25.

2. Committee for Economic Development. "Investing in our Children, Business and Public Schools," New York, 1985 .

3. Crohn, L. "Technological Literacy in the Workplace," Portland, OR: Northwest Regional Education

Laboratory, 1983.

4. Davenport, Lawrence F. "The Role of the Community College in Meeting America's Future Labor Force Needs," AACJC Journal, v. 59, February/March, $1989, \mathrm{p} .23-27$.

5. DiSalvo, Vincent $S$. and Larsen, Janet $K$. "A Contingency Approach to Communication Skill Importance: The Impact of Occupation, Direction, and Position," The Journal of Business Communication, v. 24, Summer, 1987, p. 4-19.

6. Hudson Institute. "Workforce 2000: Work and Workers for the 21st Century," Indianapolis, Indiana: Hudson Institute, Inc., 1987.

7. Johnson, Vicki M. "The Effect of Word Processing on the Business Education Curriculum," Journal of Business Education, v. 59, Number 1, October, 1983, p. 19-21.

8. Joyce, Marilyn. "An Ergonomics Primer--Part II: The Automated Workstation," Management Solutions, $v$. 33, May, 1988, p. 37-44.

9. Kirby, Margaret S. and Oliver, J. Dale. "Information Processing Specialist: A Redefinition of the Administrative Support Function," The Delta Pi Epsilon Journal, v. XXX, No. 1, Winter, 1988, p. $14-24$.

10. Klassen, Daniel L. "A Study of Computer Use and Literacy in Science Education," St. Paul Minnesota: Minnesota Educational Computing Consortium, 1980, p. 10. 
11. Metcalf, Robert. "What it Takes to be a Real Secretary," The Balance Sheet, v. 65, No. 1, September-October, 1983, p. 7-8.

12. Michael, D.N. The Unprepared Society, New York: New York Basic Books, 1968, p. 23.

13. Moon, Harry R. "A Study of the Use of Office and the Changing Role of the Management Staff in the Modern Office," Viewpoints in Education, v. 9, No. 5, February, 1984 ,

Technology Support Business p. 1-8.

14. Moon, Harry R. and Weaver, David. "Report of Survey on office Automation," Business Education Forum, December, 1984, p. 3-5.

15. Mullins, C.J. "PCs in the Office," Words, 1985, p. 13 .

16. National Center for Research in Vocational Education, Oregon Employment Division Labor Market Information, and Oregon Office of Educational Policy and Planning. "Vocational Education . . . It's Working to Prepare for a Changing Workplace," (fact sheet), 1987.

17. National Commission on Secondary Vocational Education. "The Unfinished Agenda: The Role of Vocational Education in the High School," Business Education Forum, April, 1985, p. 3-9.

18. Ostroth, D. David. "Competencies for Entry-Level Professionals: What Do Employers Look for When Hiring New Staff?" Journal of College Student Personnel, v. 22, No. 1, January, 1981, p. 5-11.

19. Parnell, Dale. The Neglected Majority, Washington, D.C.: Community College Press, 1986.

20. Professional Secretaries International. "In the Year 2020. Secretary Speakout, Research Report 143, 1987 .

21. Shaw, Mari C. "Make It Your Business: Business Education, Washington State," (pamphlet), Superintendent of Public Instruction, Olympia, Washington.

22. Smiley, James. "The Private Sector and the Business Education Department," Business Education Forum, April-May, 1986, p. 51-54. 
23. Stoufer, Bonita. "The Office of the Future," Journal of Business Education, v. 58, No. 4, January, 1983, p. 132-135.

24. U.S. Department of Labor. "Projections 2000." Occupational Outlook Quarterly, v. 31, Fall, 1987, p. 23 .

25. White, Shirley. "An Analysis of Secretarial Employment Ads with Implications for Curricular Modification," Journal of Business Education, $v$. 58 , No. 4, January, 1983, p. 135-140. 
APPENDIX A

COVER LETTER

Date

Name

Business Name

Street Address

Vancouver, WA 98661

Dear

As a business education instructor at Prairie High School, I am very interested in providing relevant career education and adequate training for students seeking entry-level work. Identifying those skills and competencies necessary for success in today's office as well as the type of equipment currently used is imperative in evaluating our curriculum and preparing qualified employees for you.

You are one of a select number of people being asked to complete a questionnaire on these topics. The results of this survey will also be the basis of a thesis paper to be presented at portland state University. You may be assured complete confidentiality. The mailing list will never be released.

If you have questions or if you are interested in our curriculum or cooperative training program (student placement in businesses), I would enjoy hearing from you.

Please take the next few minutes to check off your answers and make any comments you desire. Your participation is vital; your prompt. response and concern for qualified workers is very much appreciated.

Sincerely,

Phyllis Maki

Business Education Instructor

Cooperative Education Coordinator

Enclosure 
DIRECTIONS: Please answer all questions and ceturn this document in the pre-addressed envelope provided. All data will remain confidential.

1. Please check the industry which best describes your company:

() Financial, Investinent

() Governinent

() Insurance

( ) Legal

( ) Medical.

( ) Real Estate

( ) Other, please specify

2. Check the number of clerical/secretarial employees in your company:
( ) None
() $1-5$
() $6-10$
( ) $16-20$
() $11-15$
( ) $21-30$
() over 30

3. Indicate the brand/model of computers currently used in your company and those you plan to purchase. Check all that apply.

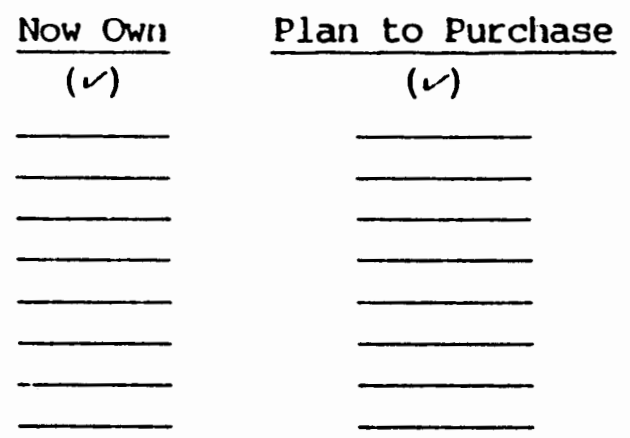

\section{Brand/Model}

Apple

Compag

Hewlett/Packard

IBM

Radio Shack

Wang

Other, please specify

Other, please specify

4. Indicate the types of software programs you own or plan to purchase. Provide the brand name of the program if possible:

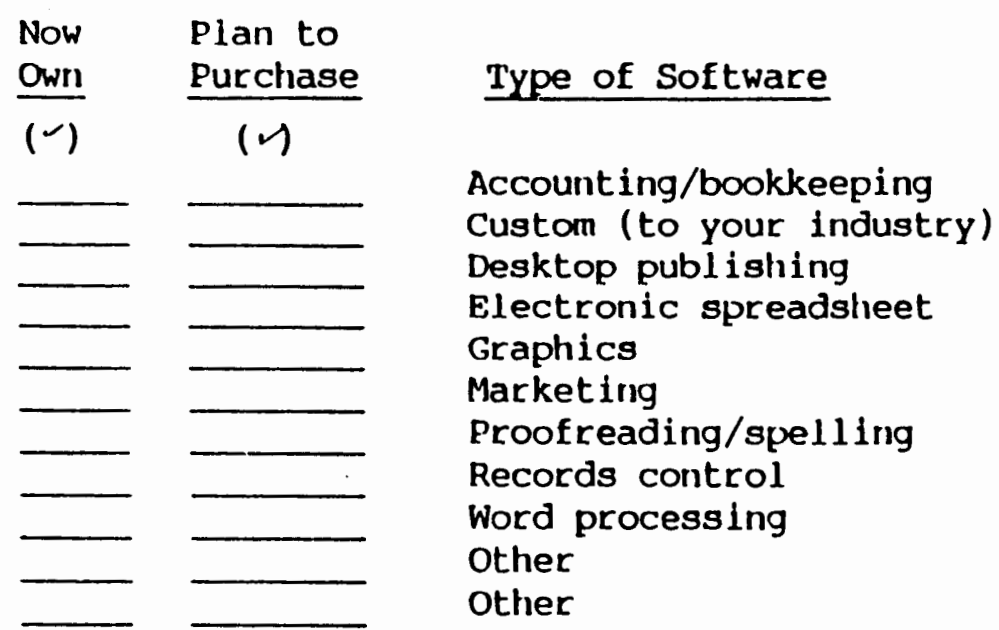

Brand Name

5. To what extent is your company using a networked system?

( ) Most/all of the time

( ) Approximately 508 of the time

( ) Rarely/not at all 
6. Indicate the degree to which you agree with the two statements below using the following scale:

5 = Strongly Agree

4 = Agree

3 = No Opinion

2 = Disagree

1 = Strongly Disagree

A. "It is very important for my company to hire high school graduates with the following competencies:"

Basic math and science skills

Interpersonal skills/hunian relations

Written/oral comnunication

Positive work habits and attitudes

Reasoning and problem-solving skills

Specific technical/vocational skills

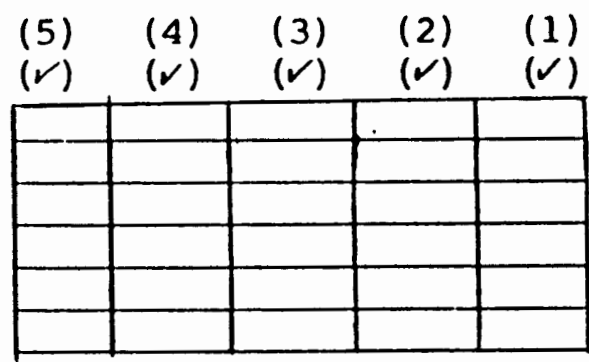

B. "It is very important for my company to hire high school graduates with the following specific technical or vocational skills:"

\begin{tabular}{|c|c|c|c|c|}
\hline $\begin{array}{l}(5) \\
(b)\end{array}$ & $\begin{array}{l}(4) \\
(4)\end{array}$ & $\begin{array}{l}(3) \\
(\sqrt{3})\end{array}$ & $\begin{array}{l}(2) \\
(v)\end{array}$ & $\begin{array}{l}(1) \\
(1)\end{array}$ \\
\hline & & & & \\
\hline & & & & \\
\hline & & & & \\
\hline & & & & \\
\hline & & & & \\
\hline & & & & \\
\hline & & & & \\
\hline & & & & \\
\hline & & & & \\
\hline & & & & \\
\hline & & & & \\
\hline & & & & \\
\hline & & & & \\
\hline
\end{tabular}

7. What changes in your information processing system do you anticipate in the next five years?

8. Complete the following sentence: "The one deficiency perceived as most common in entry-level employees is

THANK YOU FOR COMPLETING THIS QUESTIONNAIRE! If you would like a copy of the results of this study, please fill in the following information:

Name

Firm Name

Firm Address 
APPENDIX B 


\section{APPENDIX C}

BRANDS/MODELS OF COMPUTERS BUSINESS NOW OWN

(Numbers in parentheses indicate number of responses)

ALR (4)

Altos 2000

AM 3000

AST ( 5 )

AT\&T PC6300

(3)

Compac

Compac III

Data General

Data Point

DEC-7

Decwriter II

Digital (4)

Epson (7)

Exxon 500

Harris

Honeywell

Horizon

IBM Compatibles (8)

Imtec (2)

\author{
Kaypro \\ Leading Edge (7) \\ Macintosh \\ Maxar (2) \\ Micon \\ Moore Date \\ NCR \\ Panasonic Exec. Partner \\ Phillips \\ Point 4 \\ Prodata \\ Samsung (2) \\ Sperry (2) \\ Texas Instrument (6) \\ VAX \\ Vendex \\ Wyse \\ Zenith
}


APPENDIX D

OTHER SOFTWARE PROGRAMS COMPANIES USE

\author{
An Line \\ Composer \\ Debt Calc \\ Direct. Access \\ DW 4 \\ Fastback Plus \\ Framemaker \\ Framework II \\ IBM Writing Asst. \\ New Write \\ Norton Utilities \\ Novel \\ PC File \\ PC Tools \\ PFS File \\ Pathfinder \\ Print Master \\ Quiken \\ Software Tools \\ Sperry Link \\ Super Cal 4 \\ Telex \\ TValue \\ Windows \\ $\mathrm{X}$-Tree Pro
}




\author{
APPENDIX E \\ SOFTWARE USED IN SPECIFIC PROGRAM AREAS
}

(Numbers in parentheses indicate number of responses)

Accounting

AMSI

Acc Pac

Cadco

Clas

DDA

Dbase III

Double Entry

Egghead
Computer Associates

$\mathrm{G} / \mathrm{L}$

IBM (2)

Lotus

Microsoft Multiplan

Money Counts

Open Systems

Oscars

Peachtree Complete II

Poorman Douglas II

\section{Custom}

Agency Manager

Agera

Allstate

Applied Systems

CMS 600

Caselode

Clas

Client Info Plus

Colwell

Compete

Cuex

First Publisher

Lazorword
Cyma Dental Practice

Data Base Applications

Dental Plan

Hewlett Packard

Hogan

I BM

IMA

Informedics

Lifecomm

Medical Mgr.

Micro Trips

Desktop Publishing

Pagemaker (6)

Ventura
Precedent

Reflex

SBT

Systex

Tabs (3)

Time Sheets

Time Slips (4)

Ultradata

Wang
Microsoft

RPM Rental Mtg.

Sell Star

Support Calc (3)

Total Plus

Travelers Rating

Wyse

Wang

Wismer Martin

Smart Prac. (2)

Electronic Spreadsheet.
Excel/Lotus (3)
Fontasy
Microsoft Multiplan (3) Smart
Quatro
Reflex
Lotus $1-2-3$ (18)
Super Calc (4)

Xerox 
APPENDIX E (cont.)

\section{Graphics}

Auto Calc Chartmaster Fontasy (2)

Allstate

Easywriter Franework II MS Word

Allstate Data Base Applications Datavue

Word Processing

Allstate DW 4

Easywriter Excel

Framework II

IBM Textpak 6

\section{Records Control}

MS 600

PC File
Harvard Graphics (3)

McDraw/Mac (2)

Microsoft

\section{Marketing}

Complete Intelligence

(Own brand)

\section{Proofreading}

Multimate Advantage II Websters (2)

PFS Write

Word Perfect (6)
PC Paintbrush

Quatro

Reflex

RIS

Reflex Plus (2)

MS Word (2)

Microsoft Word (2)

Multimate (3)

New Word

PFS Write (2)

Professional Write (4)
Supervue

Symphony

Volkswriter 4

Word Perfect (23)

Word Prft 5.0 (6)

Word Star (2) 


\section{APPENDIX F}

SOFTWARE COMPANIES PLAN TO PURCHASE

\section{Accounting}

Informedics

Peachtree

\section{Custom}

Colwell

Desktop Publishing

Informedics

Pagemaker

Proofreading

Informedics

Word Perfect-Spellcheck

Word Processing

Word Perfect 5.0 